\title{
Isoniazid-induced Pure Red Cell Aplasia in a Patient with Sarcoidosis: A Patient Summary and Review of the Literature
}

\author{
Yasuyuki Saito ${ }^{1}$, Yuri Sawada ${ }^{1}$, Yasuhiko Koga ${ }^{1}$, Noriaki Sunaga ${ }^{1,2}$, Yusuke Tsukagoshi ${ }^{1}$, \\ Yoshimasa Hachisu ${ }^{1}$, Takashi Osaki ${ }^{1}$, Reiko Sakurai ${ }^{1}$, Kyoichi Kaira ${ }^{3}$, Akihiro Ono ${ }^{1}$, \\ Ken Sato ${ }^{1}$, Hiromi Koiso ${ }^{4}$, Tetsunari Oyama ${ }^{5}$, Takeshi Hisada ${ }^{1}$ and Masanobu Yamada ${ }^{1}$
}

\begin{abstract}
:
A 41-year-old woman treated with isoniazid (INH) for latent tuberculosis infection and an oral corticosteroid for sarcoidosis developed severe anemia two months after initiating INH. A bone marrow examination showed erythroblastopenia, and a diagnosis of INH-induced pure red cell aplasia (PRCA) was made. Her reticulocyte count and hemoglobin levels improved two weeks after discontinuation of INH. A literature review of INH-induced PRCA shows that it occurs very rarely in the context of autoimmune disorders. This report describes a case of INH-induced PRCA occurring in a patient with sarcoidosis.
\end{abstract}

Key words: isoniazid, pure red cell aplasia, sarcoidosis, autoimmune disorders, latent tuberculosis infection, biological drug

(Intern Med 56: 2753-2757, 2017)

(DOI: 10.2169/internalmedicine.8379-16)

\section{Introduction}

The routine treatment of active tuberculosis and latent tuberculosis infection (LTBI) has increased with the availability of biological drugs. The side effects of anti-tuberculosis drugs include various hematologic side effects. Reports indicate that isoniazid (INH) causes eosinophilia, leukocytosis, neutropenia, thrombocytopenia, autoimmune hemolytic anemia, pure red cell aplasia (PRCA), and sideroblastic anemia. PRCA is a rare complication caused by the disruption of hematopoiesis by INH. Secondary PRCA can be induced by viral infections, anti-erythropoietin antibodies, thymoma, chronic lymphocytic leukemia, pregnancy, drugs, and autoimmune disorders such as rheumatoid arthritis (RA), myasthenia gravis (MG), mixed connective tissue disease (MCTD), and systemic lupus erythematosus (SLE) (1).
PRCA is characterized by erythroblastopenia, with otherwise normal bone marrow production. Severe PRCA is associated with a marked decrease in the number of reticulocytes and the absence of erythroblasts in bone marrow. Drugs such as procainamide, sulfa, diphenylhydantoin, amide drugs, ticlopidine, allopurinol, penicillamine, azathioprine, and ribavirin can induce PRCA (1), but $<5 \%$ of all cases of PRCA are drug-induced. INH is also reported to induce secondary PRCA, and there have been two studies describing Asian patients with INH-induced PRCA $(2,3)$. Furthermore, cases of autoimmune disorders exacerbated by INH-induced PRCA are very rare; this is the first case report of a patient with sarcoidosis. The observations should be considered by clinicians managing patients on anti-tuberculosis treatment.

\footnotetext{
${ }^{1}$ Department of Medicine and Molecular Science, Gunma University Graduate School of Medicine, Japan, ${ }^{2}$ Oncology Center, Gunma University Hospital, Japan, ${ }^{3}$ Department of Oncology Clinical Development, Gunma University Graduate School of Medicine, Japan, ${ }^{4}$ Infection Control and Prevention Center, Gunma University Hospital, Japan and ${ }^{5}$ Department of Diagnostic Pathology, Gunma University Graduate School of Medicine, Japan

Received: October 7, 2016; Accepted: January 5, 2017; Advance Publication by J-STAGE: September 15, 2017

Correspondence to Dr. Yasuyuki Saito, sprq6fc9@road.ocn.ne.jp
} 
Table 1. Laboratory Data.

\begin{tabular}{|c|c|c|c|}
\hline Blood cell count & & Biochemistry & \\
\hline White blood cells & $4,200 / \mu \mathrm{L}$ & Total bilirubin & $1.5 \mathrm{mg} / \mathrm{dL}$ \\
\hline Neutrophils & $81.1 \%$ & AST & $35 \mathrm{IU} / \mathrm{L}$ \\
\hline Lymphocytes & $13.9 \%$ & ALT & $29 \mathrm{IU} / \mathrm{L}$ \\
\hline Eosinophils & $1.2 \%$ & LDH & $283 \mathrm{IU} / \mathrm{L}$ \\
\hline Basophils & $0 \%$ & ALP & $131 \mathrm{IU} / \mathrm{L}$ \\
\hline Monocytes & $3.8 \%$ & $\gamma$-GTP & 27 IU/L \\
\hline Red blood cells & $166 \times 10^{4} / \mu \mathrm{L}$ & Total protein & $6 \mathrm{~g} / \mathrm{dL}$ \\
\hline Hemoglobin & $5.9 \mathrm{~g} / \mathrm{dL}$ & Albumin & $3.1 \mathrm{~g} / \mathrm{dL}$ \\
\hline Hematocrit & $16.9 \%$ & Blood urea nitrogen & $13 \mathrm{mg} / \mathrm{dL}$ \\
\hline $\mathrm{MCV}$ & $101.8 \mathrm{fL}$ & Creatinine & $0.49 \mathrm{mg} / \mathrm{dL}$ \\
\hline $\mathrm{MCH}$ & $35.5 \mathrm{pg}$ & Sodium & $137 \mathrm{mEq} / \mathrm{L}$ \\
\hline MCHC & $34.9 \%$ & Potassium & $4 \mathrm{mEq} / \mathrm{L}$ \\
\hline Platelets & $5.4 \times 10^{4} / \mu \mathrm{L}$ & Chloride & $104 \mathrm{mEq} / \mathrm{L}$ \\
\hline \multirow[t]{2}{*}{ Reticulocyte count } & $2,000 / \mu \mathrm{L}$ & Calcium & $8.1 \mathrm{mg} / \mathrm{dL}$ \\
\hline & & Serum iron & $240 \mu \mathrm{g} / \mathrm{dL}$ \\
\hline Infection & & UIBC & $13 \mu \mathrm{g} / \mathrm{dL}$ \\
\hline Parvovirus B19 PCR & $<100 \mathrm{copy} / \mathrm{mL}$ & Ferritin & $557.1 \mathrm{ng} / \mathrm{mL}$ \\
\hline EBV & & Vitamin B12 & $408 \mathrm{pg} / \mathrm{mL}$ \\
\hline EA IgG & $(+)$ & Folic acid & $6 \mathrm{ng} / \mathrm{mL}$ \\
\hline EBNA IgG & $(+)$ & & \\
\hline VCA IgG & $(+)$ & Serology & \\
\hline VCA IgM & $(-)$ & CRP & $0.3 \mathrm{mg} / \mathrm{dL}$ \\
\hline Mumps & & Rheumatoid factor & $<10 \mathrm{IU} / \mathrm{mL}$ \\
\hline $\operatorname{IgM}$ & $(-)$ & Anti-nuclear antibody & 20 Index \\
\hline \multirow[t]{4}{*}{$\begin{array}{l}\text { Neutralizing } \\
\text { body }\end{array}$} & $(+)$ & & \\
\hline & & Coagulation & \\
\hline & & APTT & 31 second \\
\hline & & PT-INR & 1.07 \\
\hline
\end{tabular}

MCV: mean corpuscular volume, MCH: mean corpuscular hemoglobin, MCHC: mean corpuscular hemoglobin concentration, CRP: C-reactive protein, PCR: polymerase chain reaction, EBV: Epstein-Barr virus, EA: early antigen, EBNA: EBV nuclear antigen, VCA: virus capsid antigen, AST: aspartate transaminase, ALT: alanine transaminase, LDH: lactate dehydrogenase, ALP: alkaline phosphatase, $\gamma$-GTP: $\gamma$-glutamyl transferase, UIBC: unsaturated iron binding capacity, APTT: activated partial thromboplastin time, PT-INR: prothrombin time-international normalized ratio

\section{Case Report}

A 41-year-old woman, who had been followed-up for non-B, non-C, non-alcoholic chronic hepatitis, presented with increased exertional dyspnea and thus was hospitalized. The diagnosis was worsening interstitial pneumonia by sarcoidosis, and she was started on prednisolone (PSL) $20 \mathrm{mg}$ / day. Sarcoidosis had been diagnosed two years prior, when she had presented with pulmonary manifestations of sarcoidosis. At that time, she had had elevated angiotensinconverting enzyme and $\gamma$-globulin levels and a negative tuberculin skin test result. During the current admission, an interferon-gamma release assay (IGRA) revealed positive results. Sputum cultures were negative for Mycobacterium tuberculosis, and there was no evidence of active pulmonary tuberculosis on computed tomography (CT). We diagnosed the patient with LTBI. To prevent inducing an active case of tuberculosis due to the use of oral corticosteroid therapy,
INH treatment for LTBI was started one week after the initiation of PSL.

Approximately three months later at a routine follow-up visit, the patient reported the recurrence of exertional dyspnea starting several weeks prior. A laboratory analysis showed a hemoglobin level of $5.9 \mathrm{~g} / \mathrm{dL}$, a reticulocyte count of $2,000 / \mu \mathrm{L}(0.1 \%)$, and unchanged thrombocytopenia secondary to splenomegaly and chronic liver dysfunction (Table 1). Iron, vitamin B12, and folic acid levels were normal. CT, esophagogastroduodenoscopy, and colonoscopy showed no evidence of worsening interstitial pneumonia or internal bleeding. A bone marrow evaluation confirmed a significant decrease in the number of erythroblasts, with a high myeloid:erythroid ratio (206:1), but no cell dysplasia (Figure $\mathrm{A}$ and $\mathrm{B}$ ). There was no evidence suggesting any other collagen disease, malignant tumor, or infections such as infectious mononucleosis or erythema infectiosum. The patient had no fever, exanthema, or arthralgia, and none of her family members had infections such as infectious mononucleo- 


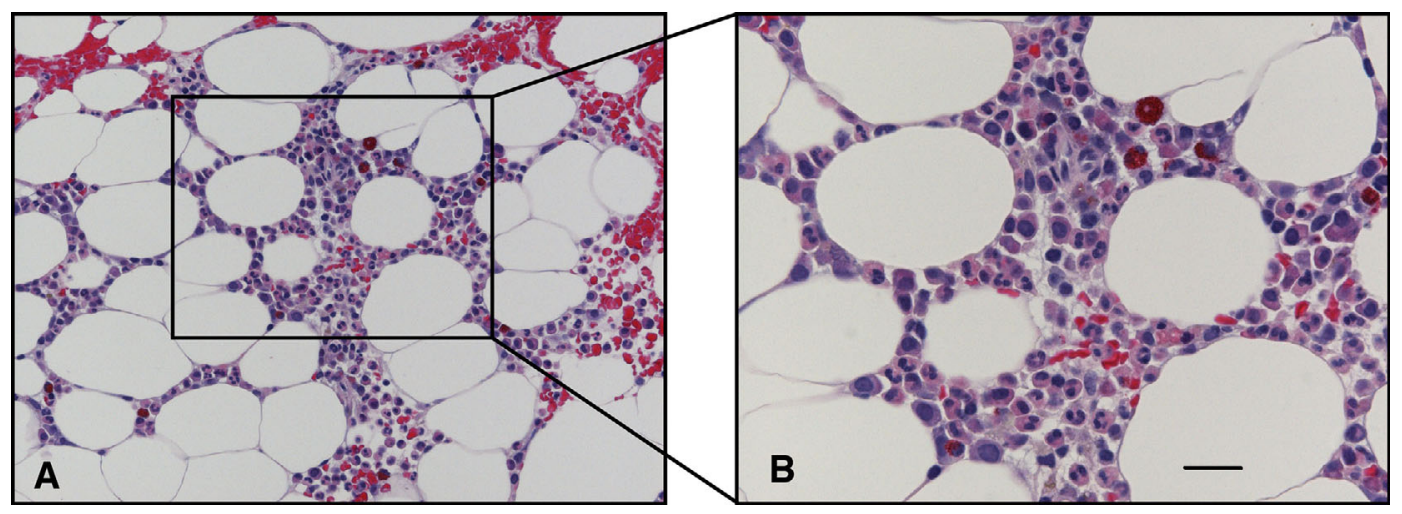

Figure. Bone marrow histology of a patient with isoniazid-induced pure red cell aplasia. The bone marrow showed marked erythroid hypoplasia with a decreased number of erythroblasts. Bar=20 $\mu \mathrm{m}$.

Table 2. Case Reports of Isoniazid-induced Pure Red Cell Aplasia.

\begin{tabular}{|c|c|c|c|c|c|c|c|c|c|c|c|c|}
\hline $\begin{array}{l}\text { Case } \\
\text { No. }\end{array}$ & $\begin{array}{c}\text { Reference } \\
\text { No. }\end{array}$ & Age & Sex & $\begin{array}{c}\text { Duration of } \\
\text { exposure } \\
\text { (months) }\end{array}$ & $\begin{array}{c}\text { Days } \\
\text { Recovery } \\
\text { (Days) }\end{array}$ & $\begin{array}{l}\text { Cooms } \\
\text { test }\end{array}$ & $\begin{array}{l}\text { Dosage } \\
\text { of } \\
\text { isoniazid } \\
(\mathrm{mg})\end{array}$ & Other drugs & Transfusion & $\begin{array}{l}\mathrm{Hb} \\
(\mathrm{g} / \mathrm{dL})\end{array}$ & $\begin{array}{c}\text { Reticulocyte } \\
(\%)\end{array}$ & Complications \\
\hline 1 & 8 & 32 & M & 6 & 6 & $(+)$ & 750 & $\begin{array}{l}\text { PAS, Pyr, } \\
\text { Insulin }\end{array}$ & $(+)$ & 4.1 & 0.1 & $\begin{array}{l}\text { Type } 1 \text { diabetes } \\
\text { mellitus }\end{array}$ \\
\hline 2 & 11 & 42 & M & 4.5 & 11 & $(-)$ & 300 & EB, Pyr, PB & $(+)$ & 5.5 & 0.2 & $\begin{array}{c}\text { Mental } \\
\text { retardation }\end{array}$ \\
\hline 3 & 11 & 66 & F & 4 & 35 & NR & NR & Pyr, PSL & $(+)$ & 7.7 & 0.1 & $(-)$ \\
\hline 4 & 11 & 53 & M & 6 & 30 & $(-)$ & 300 & Pyr & $(+)$ & 6.9 & 0.1 & Thalassemia \\
\hline 5 & 11 & 81 & M & 2 & 4 & $(-)$ & 300 & EB, Pyr & $(+)$ & 6.8 & 0.2 & $(-)$ \\
\hline 6 & 12 & 62 & M & 4 & $30-45$ & $(-)$ & 300 & Pyr, PSL & $(-)$ & 9 & 0.2 & COPD \\
\hline 7 & 12 & 72 & M & 6 & 60 & NR & 300 & RFP, ASP & $(+)$ & 11.7 & NR & Arrhythmia \\
\hline 8 & 9 & 77 & M & 3 & 14 & NR & NR & EB, Pyr, SM & $(+)$ & 5 & 0.1 & $(-)$ \\
\hline 9 & 13 & 47 & M & 1.5 & 22 & $(+)$ & 300 & RFP, EB, PRZ & $(+)$ & 7.7 & 0 & $(-)$ \\
\hline 10 & 14 & 7 & M & 9 & 45 & $(-)$ & $12 \mathrm{mg} / \mathrm{kg}$ & $(-)$ & $(+)$ & 3.6 & 0 & Liver dysfunction \\
\hline 11 & 10 & 7 & F & 6 & 15 & NR & $15 \mathrm{mg} / \mathrm{kg}$ & Pyr & $(+)$ & 6 & NR & $(-)$ \\
\hline 12 & 10 & 6 & M & 7 & 14 & NR & $15 \mathrm{mg} / \mathrm{kg}$ & Pyr & $(-)$ & 6 & NR & $(-)$ \\
\hline 13 & 15 & 79 & F & 1.5 & 10 & $(-)$ & 150 & RFP, EB, Pyr & $(-)$ & 6.3 & 1 & $(-)$ \\
\hline 14 & 2 & 47 & F & 1 & 119 & NR & 200 & PSL, TAC & $(+), \mathrm{CyA}$ & 5.8 & NR & MG, SLE \\
\hline 15 & 3 & 34 & $\mathrm{~F}$ & 6 & NR & NR & NR & NR & $(+)$ & 4 & 0.3 & $(-)$ \\
\hline 16 & $\begin{array}{l}\text { This } \\
\text { report }\end{array}$ & 41 & $\mathrm{~F}$ & 2.5 & 14 & $(-)$ & 250 & PSL & $(+)$ & 5.9 & 0.1 & Sarcoidosis \\
\hline
\end{tabular}

PAS: para-amino salicylic acid, Pyr: Pyridoxine, EB: ethambutol, PB: Phenobarbitone, NR: not reported, PSL: prednisone, COPD: chronic obstructive pulmonary desease, RFP: rifampicin, ASP: aspirin, SM: streptomycin, PRZ: pyrazinamide, TAC: tacrolimus, CyA: cyclosporin A, MG: myasthenia gravis, SLE: systemic lupus erythematosus

sis or erythema infectiosum. Furthermore, viral infections caused by parvovirus, mumps, and Epstein Barr virus were excluded by viral DNA and antibody tests. We therefore presumed that the PRCA was induced by INH, not by a viral infection. The administration of INH $250 \mathrm{mg} /$ day for 10 weeks was thus terminated, and the patient received a red blood cell transfusion. Two weeks later, the reticulocyte count had increased, and the anemia had improved. The dose of PSL was decreased, and no other medication changes were made. We diagnosed this patient with INHinduced PRCA complicated by sarcoidosis. More than one year, the patient has remained well, with stable sarcoidosis and no recurrence of PRCA.

\section{Discussion}

INH-induced PRCA is a very rare form of drug-induced PRCA, with only 16 cases reported since 1964 (Table 2). This is the first case report of a patient with sarcoidosis in the English language literature. Two cases occurring in Asian patients were reported by Nakamura et al. in 2010 (2) and Shukla et al. in 2014 (3). No influence of race or ethnicity on the onset of PRCA was found. In the present case, an oral corticosteroid was initiated for the treatment of worsening sarcoidosis, with the concomitant use of INH for LTBI. Secondary PRCA associated with autoimmune disorders such as RA, MG, MCTD, and SLE has been re- 
Table 3. Patient's Demographics.

\begin{tabular}{llr}
\hline \multicolumn{2}{c}{ Variables } & \multicolumn{1}{c}{$\mathrm{n}=16$} \\
\hline Age (year) & Median (range) & $47(6-79)$ \\
Gender & male / female & $10 / 6$ \\
Duration of exposure & (months) & 4.4 \\
Recovery days & (Days) & 29.1 \\
Cooms test & $+/-$ & $2 / 7$ \\
Transfusion & Yes / No & $13 / 3$ \\
Lowest Hb & $\mathrm{g} / \mathrm{dL}$ & 6.4 \\
Lowest reticulocyte & $\%$ & 0.2 \\
\hline
\end{tabular}

ported (4). However, very little has been reported about sarcoidosis and PRCA. Hematopoietic complications are very rare in sarcoidosis. We found two articles describing PRCA in association with sarcoidosis. In one, the patient was diagnosed with parvovirus B19-induced red blood cell aplasia and thrombocytopenia (5). In the other, sarcoidosis was complicated by red blood cell aplasia and malakoplakia (6). Evidence of a direct association between PRCA and sarcoidosis was not found in these cases, nor was it noted in the present case. INH has been shown to induce PRCA. The patient in the present case showed improvement after the discontinuation of INH. Notably, in our case, PSL was started one week prior to starting INH, suggesting that pretreatment with PSL might not have a protective effect against the development of INH-induced PRCA.

Whether or not the exacerbation of sarcoidosis requiring corticosteroid therapy affected the pathogenesis of INHinduced PRCA in our case is unclear. Mizobuchi et al. suggested that a T-cell mediated immunologic response might be associated with the pathogenesis of secondary PRCA (7). Collagen diseases such as RA and SLE are thought to be associated with PRCA. However, the relationship between PRCA and sarcoidosis remains obscure. Additional studies of drug-induced PRCA in the presence of autoimmune disorders are required to elucidate the mechanism of INHinduced PRCA.

In 16 previous reports of INH-induced PRCA (Table 2), the sex ratio was 10:6 (male:female), and the average age of onset was 47.1 years, with a wide age distribution (from infants to elderly adults). Blood transfusion was required in $>$ $80 \%$ of cases with INH-induced PRCA because the mean period of INH intake prior to the diagnosis was approximately 4.4 months (Table 3); therefore, anemia had progressed to an average hemoglobin level of $<7.0 \mathrm{~g} / \mathrm{dL}$ in patients on long-term anti-tuberculosis therapy. However, transfusion may not be mandatory, but may rather depend on the health status of the patient. Most cases of INH-induced PRCA improved after the discontinuation of INH alone, except for one case with underlying MG and SLE (2). In three cases, INH was re-administered; PRCA recurred in all three (8-10). In the case of the patient with MG and SLE, cyclosporine A was added to the existing treatment of PSL; this patient had a longer period of recovery from PRCA (119 days) (2) than the other 15 patients.
In recent years, the increased use of biological preparations has increased the need for anti-tuberculous treatment, including treatment of LTBI. Furthermore, with medical advances, various targeted molecular therapies have been developed, suggesting an even greater need for antituberculosis treatment. Therefore, the use of INH monotherapy for the treatment of LTBI, as in the present case, is expected to increase. It is therefore important to make physicians aware of INH-induced PRCA.

In summary, INH-induced PRCA presents approximately 4.4 months after starting INH. The average hemoglobin level at the diagnosis is $6.4 \mathrm{~g} / \mathrm{dL}$, as discovery often happens late. Notably, PRCA recurred in all three cases in which INH was re-administered, suggesting that this practice should be avoided.

\section{The authors state that they have no Conflict of Interest (COI).}

\section{Acknowledgement}

We wish to thank Ms. Risa Kanai and Ms. Keiko Kogure for their assistance in preparing this manuscript.

\section{References}

1. Thompson DF, Gales MA. Drug-induced pure red cell aplasia. Pharmacotherapy 16: 1002-1008, 1996.

2. Nakamura H, Okada A, Kawakami A, et al. Isoniazid-triggered pure red cell aplasia in systemic lupus erythematosus complicated with myasthenia gravis. Rheumatol Int 30: 1643-1645, 2010.

3. Shukla A, Mishra S, Jain M, Tripathi AK. Pure red cell aplasia: a rare complication of isoniazid therapy. Indian $\mathrm{J}$ Hematol Blood Transfus 30: 36-37, 2014.

4. Fisch P, Handgretinger R, Schaefer HE. Pure red cell aplasia. Br J Haematol 111: 1010-1022, 2000.

5. Viallard JF, Parrens M, Hermine O, et al. Severe prolonged red blood cell aplasia and thrombocytopenia induced by parvovirus B 19 infection in a patient with sarcoidosis. Clin Infect Dis 36: 229233, 2003.

6. Montero J, Urrutia M, Parra T, Pino A. [Testicle malacoplakia associated to aplastic anemia and cutaneous sarcoidosis]. Actas Urol Esp 1: 227-230, 1977.

7. Mizobuchi S, Yamashiro T, Nonami Y, et al. Pure red cell aplasia and myasthenia gravis with thymoma: a case report and review of the literature. Jpn J Clin Oncol 28: 696-701, 1998.

8. Goodman SB, Block MH. A case of red cell aplasia occurring as a result of antituberculous therapy. Blood 24: 616-623, 1964.

9. Lewis CR, Manoharan A. Pure red cell hypoplasia secondary to isoniazid. Postgrad Med J 63: 309-310, 1987.

10. Marseglia GL, Locatelli F. Isoniazid-induced pure red cell aplasia in two siblings. J Pediatr 132: 898-900, 1998.

11. Hoffman R, McPhedran P, Benz EJ, Duffy TP. Isoniazid-induced pure red cell aplasia. Am J Med Sci 286: 2-9, 1983.

12. Claiborne RA, Dutt AK. Isoniazid-induced pure red cell aplasia. Am Rev Respir Dis 131: 947-949, 1985.

13. Johnsson R, Lommi J. A case of isoniazid-induced red cell aplasia. Respir Med 84: 171-174, 1990.

14. Veale KS, Huff ES, Nelson BK, Coffman DS. Pure red cell aplasia and hepatitis in a child receiving isoniazid therapy. J Pediatr 120: 146-148, 1992.

15. Loulergue P, Mir O, Dhote R. Pure red blood cell aplasia and isoniazid use. Emerg Infect Dis 13: 1427-1428, 2007.

The Internal Medicine is an Open Access article distributed under the Creative 
Commons Attribution-NonCommercial-NoDerivatives 4.0 International License. To view the details of this license, please visit (https://creativecommons.org/licenses/

by-nc-nd/4.0/).

(C) 2017 The Japanese Society of Internal Medicine Intern Med 56: 2753-2757, 2017 